THURSDAY, OCTCBER 27, I88I

\section{SCIENTIFIC WORTHIES}

XVili.-James Clerk Maxwell

Born June I3, I83I ; Died November 5, 1879

$W^{E}$ have already (vol. xxi. pp. 43 and 317 ) said so much on the life and work of the late Prof. Clerk Maxwell, that in presenting his portrait as one of our Scientific Worthies, little more is necessary than to refer to the leading facts of his life. Born on June I3, 1831, he was the son of John Clerk Maxwell of Middlebie, a scion of a well-known Scottish family, the Clerks of Penicuick. When James was only eight years of age, he lost his mother, after which his father led a retired life, devoting himself to the care of his estates and of his son. The latter was educated in the first instance at the Edinburgh Academy, where in 1845 he gained the Academical Club Medal for Geometry, and the Silver Medal for Mathematics in I 847. A visit to William Nicol at this period was a marked event in his life, leading him, with apparatus of his own construction, to make observations on polarised light. A pair of prisms presented to him by Nicol were treasured by him throughout life, and three weeks before his death they were deposited in one of the show-cases of the Cavendish Laboratory.

After leaving the Academy, Maxwell, to quote the words of Prof. Tait (NATuRE, vol. xxi. p. 317), "spent the years $1847-50$ at the University of Edinburgh, without keeping the regular course for a degree. He was allowed to work during this period, without assistance or supervision, in the Laboratories of Natural Philosophy and of Chemistry: and be thus experimentally taught himself much which other men have to learn with great difficulty from lectures or books. His reading was very extensive. The records of the University Library show that he carried home for study, during these years, such books as Fourier's Théorie de la Chaleur, Monge's Géométrie Descriptive, Newton's Optics, Willis' Principles of Mechanism, Cauchy's Calcul Differentiel, Taylor's Scientific Memoirs, and others of a very high order. These were read through, not merely consulted." In October, 1850 , Maxwell went to Cambridge, entering at Peterhouse. Soon after his entry at Peterhouse, however, in December, 1850, he migrated to Trinity, where he found spirits of tastes similar to his own in the matter of physical research; here he soon became a leader among his fellows. In 1854 he came out Second Wrangler, and was bracketed as First Smith's Prizeman. In 1855 Maxwell became a Fellow of Trinity, and in 1856 he obtained the Professorship of Natural Philosophy in Marischal College, Aberdeen. To quote the memoir by Mr. W. Garnett in NATURE, vol. xxi.:- " In 1858 he married Katherine, a daughter of Principal Dewar of Marischal College, thus vacating his fellowship at Trinity. In I860 he succeeded Prof. . Goodeve as Professor of Natural Philosophy and Astronomy in King's College, London, but after the death of his father he retired in 1865 to his estate in Scotland, where he subsequently carried out his father's plans for completing the house and offices at Glenlair. In $187 \mathrm{I}$ he was invited by the Senate of the University of

VOL. XXIV.-No. 626
Cambridge to accept the Chair of Experimental Physics which had just been created, and on October 25, I87 , he delivered his inaugural lecture as Professor of Experimental Physics in the University of Cambridge. At first the most important part of his work consisted in arranging the details of the Cavendish I aboratory which the Duke of Devonshire had offered to present to the University, and the building of which was personally superintended by Prof. Maxwell from first to last. The whole of the arrangements which render the Cavendish Laboratory so admirably adapted for Physical investigations, are due to the care and forethought of Prof. Clerk Maxwell. When the building had been completed and formally presented to the University, the Duke of Devonshire further signified his desire to provide it with a comp'ete equipment of apparatus, and all this was procured under the personal supervision of the Professor. In 1872 he was elected Honorary Fellow of Trinity College, Cambridge."

During the winter of $1878-9$, Prof. Clerk Maxweli's health began to give way, and with some transient gleams of hope he gradually sank, dying on November 5, I879. He received many honours during his lifetime; he was a Fellow of the Royal Society, LL.D. of Edinburgh, and D.C.L. of Cxford ; Honorary Member of the American Academy of Arts and Sciences, the American Pbilosophical Society, and the New York Academy of Sciences; Corresponding Member of the Imperial Academy of Sciences, Vienna, and Associate of the Amsterdan Royal Academy of Sciences.

In I 860 the Rumford Medal of the Royal Society was awarded to Prof. Clerk Maxwell "for his Researches on the Composition of Colours, and other Cptical papers." In his address on the presentation of the medal, MajorGeneral Sabine alluded to Prof. Maxwell's calculation showing the connection of the "mechanical strains to which elastic solids are subjected under certain conditions with the coloured curves which those solids exhibit in polarised light."

To Clerk Maxwell's private character, to the position he unobtrusively took as a Christian, to his qualities as a poet and humorist, and to the varied work he has accomplished, it is scarcely necessary again to allude here; all these points will be found clearly brought out in the articles by Prof. Tait and Mr. Garnett above referred to. Nor is it necessary to repeat here the list of his principal papers and publications, and the great and important additions which Clerk Maxwell made to the sum of scientific knowledge, or the light he shed on the principles of the departments of science which he specially cultivated. Besides the references already given we would commend the reader who desires to have a fairly complete notion of the value of the work of the remarkable man whose portrait we give to-day, to the articles by Prof. Tait on Clerk Maxwell's "Electricity and Magnetism," vol. vii. p. 478 , "Matter and Motion," vol. xvi. p. II9, and the numerous papers by Maxwell himself scattered through the volumes of NATURE.

\section{DR. SIEMENS ON TECHNICAL EDUCATION}

FEW can read the address of Dr. C. W. Siemens to the Midland Institute, which appears in another place in our columns (p. 619), without admitting that of D D 
all living men Dr. Siemens has the best right to speak upon the relations between scientific education and the scientific industries. Himself a product of the educational system of Germany, and one of the foremost, if not in his own line the foremost, of scientific men in the industrial world, and in the land of his adoption, he yet uses no unmeaning terms when he tells us that the particular form of technical education afforded by that characteristic institution, the German Polytechnicum, "is certainly inapplicable to the condition of things which we find in this country."

The argument with which Dr. Siemens enforces this view is, so far as we are aware, a novel one from the educational point of view. He assumes frankly and without disguise that in any industry which is, like the railway system of Germany or our own telegraphic system, a Government monopoly, there is essentially a tendency to discourage improvements or any thing savouring of novelty or innovation. He also assumes that the system of "polytechnic" education fosters a like tendency, inasmuch as he thinks that, as administered in Germany, this system turns out students destitute of originality, and dogmatically persuaded that the particular machines or processes they have studied in the Polytechnicum are embodiments of perfection proved and established like propositions in Euclid. From these two premises the inference logically follows that although the Polytechnicum may be all very well for turning out young men fitted for Government appointments in a country where railways, mines, and factories are State establishments, such an institution is inappropriate in a country like England.

There is doubtless much force in this position, though the contrast between industrial conditions in Germany and England is hardly fairly represented by so sweeping a generalisation. If in a land of strong tendencies toward monopolism and conservatism the system of technical education has taken a similar bias, we should be disposed to argue that a complete system of technical education would, in a country where industrial enterprise is freer, tend toward a freer development.

On the other hand, Dr. Siemens sees plainly the inherent badness of the condition of things in England, where technical education has so long been neglected. He condemns in toto the old system of binding a lad to an apprenticeship of seven years' drudgery and mechanical routine, causing him, as such a system does, to give up thinking altogether; and is in favour of a much shorter term of pupillage.

Though he is not very explicit on the point, it is not difficult to gather the general drift of Dr. Siemens' views as to what system he would adopt in preference to the method of the German Polytechnic Colleges. Firstly, he would have science-teaching systematically incorporated in the educational curriculum of every school in the manner in which we have for years advocated, and in which Sir John Lubbock and many others have advocated it. He would also have science taught by practical work in chemical, physical, and mechanical laboratories attached to the schools. In the case of the industrial classes he would have mathematics and natural science taught to all lads before the age of fourteen, and would fix that as the minimum age at which they should be admissible to work in mines or factories. Were this done, he thinks a three years' apprenticeship would be amply sufficient to learn any mechanical trade; and he would lay upon the employer the responsibility of seeing that during this term the apprentice spent his even. ings and his Saturdays in diligent attendance at some technical or technological class where the principles underlying the operations of his business would be taught him.

We cannot too heartily endorse this last suggestion, which is now the more appropriate when not only in the metropolis but in all our chief towns and cities such classes for pure and applied science are being held under the auspices of the Science and Art Department and of the City and Guilds' Institute.

Another point on which Dr. Siemens speaks with weight is the importance of providing an adequate supply of trained teachers. Those who know the history of the attempts to render the teaching of the science classes under the Science and Art Department of greater efficiency, will heartily unite in the satisfaction expressed by Dr. Siemens concerning the reforms now in progress by which the Royal School of Mines and its associated science classes will be reorganised and developed into a Normal School of Science. The neglect and apathy of previous Governments have been indeed deplorable; but it is to be hoped that the greatest of the acknowledged defects of the national system of science-teaching are now in a fair way to be efficiently remedied.

Dr. Siemens points out that while laboratory work in schools is necessary it is comparatively inexpensive, being elementary in character. But for the efficient training not of teachers alone, but of students who have advanced beyond first principles, the delicate and elaborate appliances of exact science are more than ever essential: and for that reason "very complete laboratories are of great importance at the universities and superior colleges, where exact science and independent research take the place of mere tuition of first principles." We trust these words will not be lost in the places where they are most needed. When we look at the large and complete equipment of the mechanical, physical, and chemical laboratories of the colleges and universities to be found in every large town in Germany, France, and Switzerland, and compare them with the utterly shabby and insignificant dens which go by these names in the science colleges of Newcastle, Bristol, and Leeds, we feel that by no means the least important point of Dr. Siemens' discourse is the paragraph we have quoted above.

The concluding remarks, in which Dr. Siemens alluded to the Electrical Exhibition in Paris as pointing the moral of the inevitable changes and improvements which are continually invading every branch of industry cannot fail to impress many whose experience will confirm the truth of the observation. The plain fact remains that in the race of industrial improvements England cannot afford to stand still. And if the Continental nations have in some respects stolen a march upon us in these last years, it is not yet too late to organise and develop a system of technical education of our own adapted to our own special industrial conditions and needs. 